\title{
Pengaturan Ideal tentang Pengelolaan Daerah Aliran Sungai di Indonesia (Studi di Sungai Serang Kabupaten Kulon Progo)*
}

\author{
Nita Ariyani, Dwi Oktafia Ariyanti, dan Muhammad Ramadhan \\ Fakultas Hukum Universitas Janabadra Yogyakarta Indonesia \\ Jln. Timoho II No. 40 Kota Yogyakarta Indonesia \\ nita_ariyani@janabadra.ac.id; dwi_oktafia@janabadra.ac.id; \\ muhammad_ramadhan@janabadra.ac.id
}

Received: 21 September 2020; Accepted: 27 November 2020; Published: 15 Desember 2020 https://doi.org/10.20885/iustum.vol27.iss3.art8

\begin{abstract}
Watershed management is closely related to regulations on the affairs of local governance, water resources, spatial planning, as well as soil and water conservation. All forms of regulation relating to watershed management must be strictly regulated as the legal basis for watershed management in Indonesia. This study aims to identify, understand, and analyze the juridical constraints faced in managing watersheds in Indonesia and to analyze the ideal juridical regulatory model for watershed management in Indonesia. This research was conducted using normative juridical research, by focusing on testing the implementation of rules or norms in positive law. The results of the study show juridical constraints in watershed management in Indonesia relating to the Revocation and Substitution of the Water Resources Law; the lack of synchronization between the Water Resources Law, the Regional Government Law and the Soil and Water Conservation Law. Therefore, the authors formulate the ideal form of watershed management arrangements, among others by taking quick and effective steps through district / city regional policies while continuing to synchronize efforts through policies in the form of mandates and tasks of assisting watershed management sub-affairs.
\end{abstract}

Key Words: Ideal regulation; management; watershed

\section{Abstrak}

\begin{abstract}
Pengelolaan Daerah Aliran Sungai erat kaitannya dengan peraturan di bidang pemerintahan daerah, sumber daya air, perencanaan tata ruang, dan konservasi tanah dan air. Semua bentuk peraturan yang berkaitan dengan pengelolaan daerah aliran sungai (DAS) harus diatur secara ketat sebagai dasar hukum untuk pengelolaan daerah aliran sungai di Indonesia. Penelitian ini bertujuan untuk mengetahui, memahami, dan menganalisis kendala yuridis yang dihadapi dalam pengelolaan daerah aliran sungai di Indonesia dan menganalisis model regulasi yuridis pengelolaan DAS yang ideal di Indonesia. Penelitian ini dilakukan dengan menggunakan jenis penelitian yuridis normatif yaitu penelitian yang difokuskan pada pengujian penerapan aturan atau norma dalam hukum positif. Hasil penelitian menunjukan Kendalakendala yuridis dalam pengelolaan DAS di Indonesia berkaitan dengan Pencabutan dan Pergantian Undang-Undang Sumber Daya Air; ketidak sinkronan antara UU Sumber Daya Air, UU pemerintahan Daerah dan UU Konservasi Tanah dan Air. Oleh karenanya penulis merumuskan bentuk pengaturan ideal pengelolaan DAS antara lain dengan mengambil langkah-langkah yang cepat dan efektif melalui kebijakan-kebijakan daerah kabupaten/kota dengan tetap melakukan upaya sinkronisasi melalui kebijakan berupa mandat dan tugas pembantuan sub-urusan pengelolaan DAS.
\end{abstract}

Kata-kata Kunci: Pengaturan ideal; pengelolaan; daerah aliran sungai 


\section{Pendahuluan}

Pasal 33 ayat (3) UUD NRI 1945 menyatakan bahwa "Bumi dan air dan kekayaan alam yang terkandung di dalamnya dikuasai oleh negara dan dipergunakan untuk sebesar-besar kemakmuran rakyat." Daerah Aliran Sungai (DAS) merupakan bagian dari bumi yang mengandung air dan mengandung kekayaan alam sehingga harus dilindungi, diatur, dikuasai dan dikelola oleh negara dalam rangka untuk mewujudkan kemakmuran bagi rakyat. Pengelolaan DAS adalah upaya manusia dalam mengatur hubungan timbal balik antara sumber daya alam dengan manusia di dalam DAS dan segala aktivitasnya, agar terwujud kelestarian dan keserasian ekosistem serta meningkatnya kemanfaatan sumber daya alam bagi manusia secara berkelanjutan. Pengelolaan dan pengendalian DAS di Indonesia pada tataran praktik belum berjalan dengan baik karena: pertama, kerusakan DAS berkaitan dengan tingkat sosial ekonomi masyarakat di daerah tengah hingga hulu DAS; kedua, tingkat kesadaran dan kemampuan ekonomi masyarakat yang rendah karena mendahulukan kebutuhan primer dan kebutuhan sekunder; ketiga, masyarakat belum sepenuhnya memberikan kepedulian terhadap lingkungan sehingga sering terjadi penurunan kualitas ekosistem; keempat, penggunaan atau pemanfaatan hutan dan lahan yang tidak sesuai dengan kaidahkaidah konservasi dan melampaui kemampuan daya dukungnya, akan menyebabkan terjadinya lahan kritis. ${ }^{1}$ Kerusakan DAS juga dicirikan dengan luasnya lahan kritis yang menyebabkan fungsi DAS dalam tata air tidak optimal sehingga frekuensi dan besaran banjir dan kekeringan semakin meningkat. ${ }^{2}$

Berdasarkan SK Menteri Kehutanan Nomor SK. 328/Menhut-II/2009 tanggal 12 Juni 2009 tentang Penetapan Daerah Aliran Sungai (DAS) Prioritas Dalam Rangka Rencana Pembangunan Jangka Menengah (RPJM) 2010-2014 telah ditetapkan sebanyak 108 DAS di Indonesia dalam kondisi kritis dan menjadi prioritas untuk penanganan dan pemulihanan DAS. ${ }^{3}$ Salah satu DAS kritis yang menjadi prioritas pemulihan DAS adalah DAS pada Sungai Serang yang terletak

\footnotetext{
${ }^{1}$ Penjelasan Peraturan Daerah Daerah Istimewa Yogyakarta Nomor 11 Tahun 2016 tentang Pengelolaan Daerah Aliran Sungai

${ }^{2}$ Khabibi Nurrofi' Pratama, Kukuh Murtilaksono, Hendrayanto, "Pengembangan Kelembagaan Penggunaan Lahan Di Das Catur Kabupaten Madiun," Jurnal Tataloka, Volume 19, No. 2, Mei 2017, hlm. 129-130.

3 Muhammad Fatahilah, "Kajian Keterpaduan Pengelolaan Daerah Aliran Sungai (Das) Garang Provinsi Jawa Tengah", Jurnal Geografi, Volume 10 No. 2, Juli 2013, hlm. 137
} 
di Kabupaten Kulon Progo. DAS Serang yang terletak di Kabupaten Kulon Progo terdiri dari Sub DAS Nagung, Sub DAS Ngrancah, Sub DAS Serang Hilir, Sub DAS Serang Sekiyep, Sub DAS Sidatan dan Sub DAS Sumitro. Luas total DAS Serang adalah 23.931,28 Ha. ${ }^{45}$ DAS Serang menurut Keputusan Menteri Pekerjaan Umum Nomor: 590/KPTS/M/2010 juga merupakan salah satu DAS kritis di Daerah Istimewa Yogyakarta. DAS Serang mengalami kerusakan lingkungan parah baik dari aspek biotik maupun abiotik/fisik. Tingkat bahaya erosi di DAS Serang yang terberat terletak di kecamatan Kokap seluas 4365,57 Ha. Tingkat kekritisan lahan di Serang terjadi di sub DAS Nagung, Sub DAS Ngrancah, Sub DAS Serang Sekiyep dan Sub DAS Sidatan. ${ }^{6}$

Berdasarkan penelitian disertasi Agung Setyawan, tingkat kerusakan lingkungan DAS Serang Kulonprogo terjadi di wilayah SubDAS Soemitro, Ngrancah dengan kerusakan tinggi, wilayah Sekiyep dengan tingkat kerusakan lingkungan sedang, dan wilayah Sidatan dan Nagung dengan tingkat kerusakan rendah.7 DAS Serang Kabupaten Kulonprogo D.I. Yogyakarta pada daerah hulu berpontensi sebagai jasa pengaturan tata air dan banjir terutama di Kecamatan Kokap dengan persentase luasan jasa lingkungan pengaturan tata air dengan kelas sangat tinggi sebesar 85\% dari luas Kecamatan Kokap, serta masih minimnya tingkat etika lingkungan masyarakat di DAS Serang Kabupaten Kulonprogo D.I. Yogyakarta. ${ }^{8}$

Pengelolaan DAS secara terpadu sangat diperlukan dengan melibatkan pemangku kepentingan pengelolaan sumberdaya alam yang terdiri dari unsur-unsur masyarakat, dunia usaha, pemerintah, dan pemerintah daerah dengan prinsipprinsip keterpaduan, kesetaraan, dan berkomitmen untuk menerapkan penyelenggaraan pengelolaan sumberdaya alam yang adil, efektif, efisien, dan berkelanjutan. Dalam penyelenggaraan pengelolaan DAS terpadu tersebut

\footnotetext{
4 Tim Penyusun, Rencana Pengelolaan Daerah Aliran Sungai Serang Tabun 2012-2027, Kementerian Lingkungan Hidup dan Kehutanan Direktorat Jenderal Pengendalian Daerah Aliran Sungai dan Hutan Lindung Balai Pengelolaan Daerah Aliran Sungai dan Hutan Lindung Serayu,Opak, Progo., 2017, hlm. 3.

${ }^{5}$ Ibid.

${ }^{6}$ Ibid., hlm. 12-13

7 Agung Setyawan, Totok Gunawan, Suprapto Dibyosaputro, Sri Rum Giyarsih, Jasa Dan Etika Lingkungan Untuk Pengendalian Air Dan Banjir Sebagai Dasar Pengelolaan Das Serang. Jurnal Pembangunan Wilayah \& Kota, Voume 14 Nomor 4, Desember 2018, hlm. 241. https://doi.org/10.14710/pwk.v14i4.21096 8 Ibid., hlm. 250
} 
diperlukan perencanaan yang komprehensif yang mengakomodasikan berbagai pemangku kepentingan (stakeholders) melalui pengaturan pengelolaan DAS secara tegas dan jelas.

Artikel ini akan menjelaskan kendala-kendala yuridis yang dihadapi dalam pengelolaan DAS di Indonesia dengan studi kasus di DAS Sungai Serang yang terletak di Kabupten Kulon Progo, Provinsi Daerah Istimewa Yogyakarta khususnya berkaitan dengan peraturan perundang-undangan yang berkaitan dengan kewenangan pengelolaan DAS banyak yang belum sinkron antara peraturan yang satu dengan yang lain baik secara vertikal maupun horisonal. Artikel ini juga akan menjelaskan mengenai pengaturan ideal terkait pengelolaan DAS di Indonesia dengan mengambil studi kasus di DAS Sungai Serang Kabupaten Kulon Progo. Beranjak dari berbagai permasalahan di atas, tentunya penelitian ini menjadi sangat urgen guna memberikan masukan atas riset ilmu hukum khususnya mengenai diskursus pengelolaan DAS di Indonesia dari segi yuridis yang masih cukup terbatas.

\section{Rumusan Masalah}

Berdasarkan latar belakang tersebut di atas, maka dirumuskan permasalahan sebagai berikut. Pertama, kendala-kendala yuridis apa saja yang dihadapi dalam pengelolaan DAS di Sungai Serang, Kabupaten Kulon Progo? Kedua, bagaimanakah bentuk pengaturan ideal terkait pengelolaan DAS di Indonesia?

\section{Tujuan Penelitian}

Tujuan dari penelitian dengan judul "Pengaturan Ideal tentang Pengelolaan Daerah Aliran Sungai di Indonesia (Studi di Sungai Serang Kabupaten Kulon Progo)" adalah sebagai berikut: pertama, untuk mengetahui, memahami dan menganalisis kendala-kendala yuridis yang dihadapi dalam pengelolaan DAS di Indonesia dengan studi kasus di DAS Sungai Serang yang terletak di Kabupten Kulon Progo, Provinsi Daerah Istimewa Yogyakarta. Kedua, untuk mengetahui, memahami dan menganalisis bentuk pengaturan yuridis secara ideal terkait pengelolaan DAS di Indonesia. 


\section{Metode Penelitian}

Tipe penelitian yang digunakan adalah yuridis normatif yaitu penelitian yang difokuskan untuk mengkaji penerapan kaidah-kaidah atau norma-norma dalam hukum positif. ${ }^{9}$ Metode pendekatan yang digunakan adalah pendekatan undang-undang (statute approach), pendekatan analitis (Analytical Approach) dan pendekatan kasus (Case approach). ${ }^{10}$ Penulis menginventarisasi dan mengkaji beberapa peraturan perundang-undangan yang berkaitan dengan pengelolaan DAS, menggunakan teori hierarki peraturan perundang-undangan, tata urutan peraturan perundang-undangan di Indonesia, asas-asas pembentukan peraturan perundang-undangan dan konsep pengelolaan daerah aliran sungai untuk menemukan kendaala-kendala yuridis pengelolaan DAS dan merumuskan model ideal pengaturan pengelolaan DAS di Indonesia. Beberapa pendekatan digunakan untuk membentuk polarisasi pemikiran yang lebih lengkap dan detail terhadap pokok permasalahan yang diteliti.

Lokasi penelitian dilakukan di Balai Pengelolaan DAS DIY, Perpustakaan Pusat Universitas Janabadra, Perpustakaan Universitas Islam Indonesia, Perpustakaan Universitas Gadjah Mada, Perpustakaan Kota Yogyakarta dan Perpustakaan Grahatama. Sumber data menggunakan data sekunder dan data primer. Data primer dihasilkan dari penelitian lapangan. Data sekunder berasal dari bahan-bahan hukum yang terdiri dari : a. bahan hukum primer terdiri dari Undang-Undang Dasar Negara Republik Indonesia tahun 1945, beberapa peraturan peraturan perundang-undangan yang berkaitan dengan pengelolaan DAS termasuk didalamnya beberapa peraturan pelaksana yang mengatur secara khusus mengenai pengelolaan DAS. b. bahan hukum sekunder terdiri dari bukubuku literatur, majalah ilmiah, artikel ilmiah, jurnal ilmiah, dokumen-dokumen resmi yang berkaitan dengan masalah yang diteliti, makalah, hasil penelitian dan sumber dari internet. c. bahan hukum tersier menggunakan kamus hukum dan ensiklopedia untuk memberikan petunjuk atau penjelasan bermakna terhadap bahan hukum primer dan sekunder. hlm. 3 .

9 Johnny Ibrahim, “Teori dan Metodologi Penelitian Hukum Normatif”, Bayu Media Publishing, Malang, 2011, 10 Peter Mahmud Marzuki, "Penelitian Hukum”, Prenada Media Grup, Jakarta, 2009, hlm. 93. 
Data yang diperoleh dianalisa dengan metode kualitatif yaitu menjabarkan dan memberikan interpretasi terhadap data yang diperoleh berdasarkan normanorma hukum, teori-teori dan doktrin yang berlaku dihubungkan dengan pokok permasalahan. Substansi atau isi maupun struktur hukum positip yang berkaitan dengan pengelolaan DAS dideskripsikan dan dijabarkan serta diinterpretasikan dengan berdasarkan norma-norma hukum yang lebih tinggi mulai dari UUD NRI 1945, teori-teori hierarki peraturan perundang-undangan, tata urutan peraturan perundang-undangan di Indonesia, asas-asas pembentukan peraturan perundang-undangan dan konsep pengelolaan daerah aliran sungai dalam upaya menemukan kendala-kendala yuridis dalam pengelolaan DAS serta dalam rangka menganalisis model ideal pengaturan pengelolaan DAS di Indonesia, Studi kasus di Sungai Serang Kabupaten Kulonprogo.

\section{Hasil Penelitian dan Pembahasan}

Istilah Daerah Aliran Sungai (DAS) memiliki banyak istilah dan pemaknaan antara lain cacthment area, watershed, atau drainage basin. ${ }^{11}$ DAS dalam bahasa Inggris disebut Watershed atau dalam skala luasan kecil disebut Catchment Area adalah suatu wilayah daratan yang dibatasi oleh punggung bukit atau batasbatas pemisah topografi, yang berfungsi menerima, menyimpan dan mengalirkan curah hujan yang jatuh di atasnya ke alur-alur sungai dan terus mengalir ke anak sungai dan ke sungai utama, akhirnya bermuara ke danau/waduk atau ke laut. ${ }^{12}$ Daerah Aliran Sungai (DAS) merupakan satu kesatuan ekosistem yang unsurunsur utamanya terdiri atas sumberdaya alam tanah, air, vegetasi, dan sumberdaya manusia sebagai pelaku pemanfaat sumberdaya alam tersebut. ${ }^{13}$

Daerah Aliran Sungai (DAS) berdasarkan Pasal 1 ayat (1) Peraturan Pemerintah Nomor 37 Tahun 2012 tentang Pengelolaan Daerah Aliran Sungai adalah suatu wilayah daratan yang merupakan satu kesatuan dengan sungai dan anak-anak sungainya, yang berfungsi menampung, menyimpan dan mengalirkan air yang

\footnotetext{
11 Sudaryono, "Pengelolaan Daerah Aliran Sungai (Das) Terpadu, Konsep Pembangunan Berkelanjutan," Jurnal Teknologi Lingkungan, Volume 3, No. 2, Mei 2002, hlm. 153.

12 Naharuddin, Herman Harijanto, and Abdul Wahid, Pengelolaan Daerah Aliran Sungai Dan Aplikasinya Dalam Proses Belajar Mengajar, Cetakan Pertama, UNTAD Press, Palu, 2018, hlm. 4.

${ }^{13}$ Ismah Pudji Rahayu Ishak, Andi Idham Asman, Despry Nur Annisa Ahmad, "Pemanfaatan Teknologi Spasial Dalam Pengelolaan Daerah Aliran Sungai (Das) Binanga Lumbua Kabupaten Jeneponto Sulawesi Selatan”, Jurnal Geomatika, Volume 22 Nomor 1, Mei 2016, hlm. 2.
} 
berasal dari curah hujan ke danau atau ke laut secara alami, yang batas di darat merupakan pemisah topografis dan batas di laut sampai dengan daerah perairan yang masih terpengaruh aktivitas daratan. Sedangkan yang dimaksud dengan Pengelolaan DAS menurut Pasal 1 ayat (2) PP Nomor 37 Tahun 2012 adalah upaya manusia dalam mengatur hubungan timbal balik antara sumber daya alam dengan manusia di dalam DAS dan segala aktivitasnya, agar terwujud kelestarian dan keserasian ekosistem serta meningkatnya kemanfaatan sumberdaya alam bagi manusia secara berkelanjutan. Pengelolaan DAS pada prinsipnya adalah pengaturan tata guna lahan atau optimalisasi penggunaan lahan untuk berbagai kepentingan secara rasional serta praktek lainnya yang ramah lingkungan sehingga dapat dinilai dengan indikator kunci (ultimate indicator) kuantitas, kualitas dan kontinuitas aliran sungai pada titik pengeluaran (outlet) DAS. 14

Pengelolaan DAS bertujuan untuk memperbaiki, memelihara dan melindungi kondisi DAS agar menghasilkan kontinuitas produktivitas air (water yield) untuk kepentingan pertanian, kehutanan, perkebunan, peternakan, perikanan, industri dan masyarakat. ${ }^{15}$ Kerusakan DAS di Indonesia semakin meningkat dari tahun ke tahun karena antara lain adanya kebutuhan lahan yang semakin tinggi seiring dengan bertambahnya jumlah penduduk.

Meningkatnya kepentingan pembangunan sektoral dan daerah yang berakibat pada berubahnya status, fungsi dan peruntukan kawasan hutan menjadi penggunaan lain juga menjadi penyebabnya. Kerusakan DAS ini memerlukan pengelolaan yang tepat sesuai dengan kondisi administrasi pemerintahan, kelembagaan, sosial kemasyarakatan dan biofisiknya. ${ }^{16}$ Berikut hasil dan analisis penelitian mengenai pengelolaan ideal DAS di Indonesia dibatasi dalam sudut pandang ilmu hukum yang utama dan ilmu lain sebagai pendukung.

14 Adi Susetyaningsih, "Pengaturan Penggunaan Lahan di Daerah Hulu Das Cimanuk Sebagai Upaya Optimalisasi Pemanfaatan Sumberdaya Air," Jurnal Konstruksi Sekolah Tinggi Teknologi Garut, Volume 10, No. 01, Tahun 2012, hlm.3.

${ }^{15}$ H. Satriawan, Strategi Pengelolaan Daerah Aliran Sungai (Das) Dalam Rangka Optimalisasi Kelestarian Sumberdaya Air (Studi Kasus DAS Peusangan Aceh). Majalah Ilmiah Universitas Almuslim, Volume 9 (Edisi Khusus Dies Natalies), 2017, hlm. 29. http://www.jurnal.umuslim.ac.id/index.php/VRS/article/viewFile/ 912/878, diakses pada tanggal 18 September 2020

${ }_{16}$ Menlhk, "DAS Kritis: Tantangan Sains Pengelolaan DAS Di Indonesia," http://www.menlhk.go.id/, 2018, http://www.menlhk.go.id/site/single_post/1618., diakses pad tanggal 18 September 2020 


\section{Kendala-Kendala Yuridis dalam Pengelolaan Daerah Aliran Sungai Serang}

Berkaitan dengan pengelolaan DAS di Indonesia terdapat kurang lebih sekitar 108 DAS kritis yang diprioritaskan untuk harus dipulihkan/ditangani berdasarkan Surat Keputusan Menteri Kehutanan Nomor 328/Menhut-II/2009 tanggal 12 Juni 2009 tentang Penetapan Daerah Aliran Sungai (DAS) Prioritas Dalam Rangka Rencana Pembangunan Jangka Menengah (RPJM) Tahun 20102014. DAS- DAS di Provinsi DIY termasuk yang menjadi prioritas untuk pemulihan DAS yang meliputi :DAS Bribin terletak di Kabupaten Gunungkidul; DAS Serang terletak di Kabupaten Kulon Progo; DAS Opak terletak di Kabupaten Sleman, Kabupaten Bantul, Kabupaten Gunungkidul, dan Kota Yogyakarta; dan DAS Progo Hilir terletak di Kabupaten Sleman, Kabupaten Bantul dan Kabupaten Kulon Progo. DAS Serang, DAS Progo Hilir, DAS Bribin, dan DAS Opak menjadi DAS prioritas untuk dilakukan pemulihan lingkungan DAS baik dari aspek fisik maupun sosial ekonomi masyarakatnya. ${ }^{17}$

Pengelolaan DAS di Sungai Serang Kabupaten Kulon Progo memerlukan suatu pengaturan hukum yang efektif agar pemulihan lingkungan DAS baik fisik maupun sosial ekonomi masyarakatnya dapat segera ditangani. Kementerian Lingkungan Hidup dan Kehutanan, Direktorat Jenderal Pengendalian Daerah Aliran Sungai dan Hutan Lindung, Balai Pengelolaan Daerah Aliran Sungai dan Hutan Lindung Serayu Opak Progo telah memiliki Rencana Pengelolaan Daerah Aliran sungai Progo 20122027. Dalam Rencana pengelolaan DAS pada Sungai Serang, telah mengidentifikasi masalah pada DAS Sungai Serang antara lain: pertama, permasalahan biogeofisik meliputi permasalahan sumber daya lahan (land resources). permasalahan sumber daya air (water resources), erosi dan sedimentasi. Kedua, permasalahan sosial. budaya dan kelembagaan, koordinasi dan sinergi dalam pengelolaan DAS secara terpadu. ${ }^{18}$ Ketiga, permasalahan ketidaksinkronan peraturan perundang-undangan berkaitan dengan kewenangan pengelolaan DAS.

Ditinjau secara umum permasalahan biogeofisik mengidentifikasikan terjadinya penurunan terhadap fungsi-fungsi perlindungan, produksi, resapan air, tata air yang menimbulkan gangguan dan atau berpeluang terhadap kondisi

\footnotetext{
17 Penjelasan Peraturan Daerah DIY Nomor 11 Tahun 2016 tentang Pengelolaan Daerah Aliran Sungai

${ }^{18}$ Kementerian Lingkungan Hidup..., Op. Cit., hlm. 55
} 
ekstrim perilaku hidrologi sehingga mengakibatkan kerentanan terhadap meningkatnya erosi dan sedimentasi, morfoerosi baik berupa jatuhan (falls), longsor (land slide), aliran (flows), rayapan (creep) bahkan bandang (debris, torrents), banjir dan kekeringan, semakin menurunnya water yield sehingga berpengaruh terhadap penurunan potensi air tanah. potensi air permukaan dan penurunan potensi sumber mata air. Adapun permasalahan biogeofisik yang berhasil diidentifikasi di DAS Serang sebagai bcrikut: ${ }^{19}$

Tabel 1.

Permasalahan Pengelolaan DAS Serang dari Aspek Biogeofisik

\begin{tabular}{ll}
\hline No $\quad$ Aspek Biofisik & Permasalahan \\
\hline 1. Sumber Daya Lahan
\end{tabular}
a. Tata Ruang dan Penggunaan lahan
1. Penyimpangan penggunaan lahan yang tidak sesuai dengan RTRW mencapai $>56 \%$ (Hasil Penelitian IPB)
2. Banyak terdapat permukiman di Kawasan hulu DAS yang merupakan kawasan hutlan lindung dan hutan konservasi. Persil-persil lahan dimiliki oleh penduduk sehingga sulit melakukan pengaturan permukiman.

3. Luasan hutan masih kurang dari $30 \%$

b. Penutupan

Lahan/Land Cover

(Hutan Lindung,

Hutan Konservasi,

Kawasan Budidaya,

Kawasan Pemukiman

Perkotaan)

c. Lahan

(penyebab, distribusi)
Kritis 1. Banyak Lahan Kas Desa yang belum di manfaatkan atau masih berupa lahan kosong.

2. Struktur tanah dan batuan yang memang sulit di konservasi

3. Tindakan konservasi dan penggunaan lahan yang tidak tepat.

2. Sumber Daya Hutan/Vegetasi

Tumbuh perumahan. ruko, bangunan umum dll di pinggir sungai (sempadan sungai) yang rawan banjir (Kec. Wates dan Kec. Pengasih). tegakan (rendah, sedang, rapat)
a. Kondisi kerapatan 1 .
. Pola tebang dan tanam di hutan produksi yang tidak tepat (penanaman dilakukan setelah penebangan, ada jeda lahan tcrbuka sebelum tanaman baru tumbuh besar.
2. Kondisi keraptan vegetasi dari tahun ke tahun yang terus mcnurun (semakin jarang kerapatannya) 


b. Kondisi
Keanekaragaman
hayati/flora/fauna
(satu jenis/banyak
jenis)

1. Jenis tanaman di hutan produksi (Hulu) kurang bervariasi. Jenis tanaman di hutan produksi umumnya berupa hutan rakyat yang ditanami sengon dengan kombinasi jati dan mahoni yang merupakan tanaman produksi kayu

2. Tanaman langka di sekitar waduk sermo yang ditetapkan sebagai tanaman yang dilindungi dengan peraturan gubernur kondisinya sudah tua dan membahayakan karena rawan tumbangdan patah batangnya

3. Jenis tanaman lokal yang mulai jarang dijumpai
c. Kondisi biomassa/ Pada hutan lindung / kawasan konservasi kondisi seresah (sedikit. seresah sedikit sedang, banyak)
d. Lainnya

3. Erosi dan Sedimentasi

a. Erosi

b. Sedimentasi

c. Daerah Rawan

(Banjir,Longsor, Kekeringan)

4. Kegiatan Pertambangan

5. Wilayah Pesisir
1. Erosi disebabkan oleh struktur atau kondisi alamiah tanah yang mudah ter-erosi (Kec. Samigaluh)

2. Lahan kritis mcmiliki potensi alamiah dan karena konservasi yang tidak sesuai

Sedimentasi terlihat dari pendangkalan waduk Sermo (data dapat diperoleh di PSDA Sermo)

1. Sering terjadi longsor tebing sungai di Desa Sidomulyo

2. Sumber mata air terbatas dengan debit yang kecil (Desa Sidomulyo)

1. Di desa Kalirejo terdapat tambang emas yang menggunakan air dari mata air dusun Lampang.

2. Potensi tambang batu andesit di bukit sekitar sungai dapat menyebabkan kerusakan lingkungan

1. Air tanah di Kec. Panjatan terpengaruh oleh intrusi air laut sehingga rasanya asin.

2. Peralatan destilasi untuk mengubah air tanah yang asin menjadi air tawar di Desa Bugel harganya cukup mahal. Penyaluran hasil destilasi menggunakan gallon dengan harga Rp. 2000/gallon

Sumber: Kementerian Lingkungan Hidup dan Kehutanan Direktorat Jenderal Pengendalian Daerah Aliran Sungai dan Hutan Lindung Balai Pengelolaan Daerah Aliran Sungai dan Hutan Lindung Serayu, Opak, Progo 
Berkaitan dengan permasalahan Sosial, ekonomi, Budaya dan Kelembagaan yang berhasil diindentifikasi oleh Balai Pengelolaan Daerah Aliran Sungai dan Hutan Lindung Serayu Opak Progo antara lain sebagai berikut.

Tabel 2.

Permasalahan Pengelolaan DAS Serang (Aspek Sosial, Ekonomi, Budaya dan Kelembagaan)

No Isu Strategis/Permasalahan

1. Ketahanan Pangan

a. Alih Fungsi lahan pertanian (banyak terjadi di kawasan perkotaan).

b. Belum ada intensif dan disinsentif dari penetapan LP2B

c. Masih terdapat beberapa daerah yang termasuk rawan pangan

d. Perubahan kondisi lingkungan yang mempengarulii pola tanam

2. Kerusakan Lingkungan

a. Kelembagaan di Kabupaten Kulon Progo yang berkaitan dengan DAS masih terintegrasi (multisektoral).

b. Kelembagaan pada tingkat petani belum efektif

c. Gagal panen akibat banjir yang berasal dari hulu DAS Serang karena debit air yang melimpas.

d. Kerusakan tanggul (alami)di sepanjang DAS Serang. Tanggul alami sering dimanfaatkan sebagai lahan pertanian, sehingga fungsi tanggul tidak optimal.

e. Kerusakan lingkungan pada bagian hilir (mangrove).

f. Bencana yang diakibatkan oleh perilaku manusia/aktivitas sosial ekonomi: - longsor: perilaku menanam tanaman pangan di daerah kemiringan lereng yang jeram atau di sempadan (atau di kawasan lindung)

- Banjir: terjadi karena sedimentasi sehingga sungai mengalami pendangkalan.

- Sedimentasi: penggunaan lahan kosong (sempadan sungai) untuk pertanian.

3. Kearifan Lokal dan Perilaku (Konservasi)

a. Bentuk kearifan lokal belum semuanya terwadahi/terakomodasi dengan baik.

b. Perilaku konservasi di wilayah hilir (Sentolo, Triharjo, Bendungan dll) masih rendah (bantaran banjir dan sempadan sungai masih dimanfaatkan sebagai lahan pertanian

4. Penambangan Liar

a. Penegakan hukum masih lemah.

b. Ketidaksesuaian perjanjian/kontrak dengan kondisi di lapangan, terutama pasca dilakukannya penambangan.

c. Sanksi hukum bagi penambang masih terlalu ringan (sanksi yang diberikan lebih rendah dibandingkan dengan keuntungan, sehingga tidak menimbulkan efek jera) 
5. Pedangkalan/Penyempitan DAS

a. DAS Serang sudah mulai mengalami pendangkalan. Fluktuasi debit air di DAS Serang pada musim kemarau dan penghujan cukup tinggi.

b. Air sungai DAS Serang yang kerus pasca hujan turun.

c. Pendangkalan yang diakibatkan oleh pemanfaatan lahan (sempadan) untuk kegiatan pertanian.

6. Peraturan Perundangan

a. Masyarakat belum memahami produk-produk hukum tentang sumber daya air, terutama yang terkait dengan DAS.

b. Belum ada RDTR Kawasan Pesisir.

c. Sinkronisasi peraturan perundangan belum begitu diperhatikan

d. Peraturan perundangan tentang DAS di Kulon Progo belum spesifik

7. Kesadaran, Pengetahuan dan Pendidikan (Sumber Daya Manusia)

a. Pengetahuan masyarakat di sekitar DAS masih kurang terkait dengan tingkat pendidikan masyarakat yang masih rendah).

b. Akses masyarakat terhadap pendidikan masih tcrbatas.

c. Regenerasi petani masih sulit

d. Kurangnya pengetahuan dan kesadaran masyarakat tentang pengelolaan DAS

8. Kelembagaan

a. Peran forum DAS belum optimal (Masih banyak petani masyarakat di sekitar DAS Serang yang masih minim pengetahuannya tentang pengelolaan lingkungan di sekiiar DAS maupun peraturan perundangan tentang DAS

b. Belum merata kelembagaan di tingkat kecamatan dan desa yang spesifik menangani DAS

Sumber: Kementerian Lingkungan Hidup dan Kehutanan Direktorat Jenderal Pengendalian Daerah Aliran Sungai dan Hutan Lindung Balai Pengelolaan Daerah Aliran Sungai dan Hutan Lindung Serayu,Opak, Progo

Pemerintah Pusat melalui Balai Pengelolaan Daerah Aliran Sungai dan Hutan Lindung Serayu Opak Progo telah menyusun Rencana pengelolaan DAS Serang untuk jangka waktu 15 Tahun (2012-2027) namun dalam implementasinya memiliki beberapa kendala-kendala yuridis antara lain sebagai berikut.

\section{Kendala Yuridis berupa Pencabutan dan Pergantian Undang-Undang berkaitan dengan Sumber Daya Air}

Pencabutan dan Pergantian beberapa peraturan perundang-undangan yang dijadikan landasan hukum dalam pengelolaan DAS di Indonesia menjadi kendala yuridis dalam pengelolaan DAS di Indonesia. Hal ini karena apabila suatu peraturan perundang-undangan yang menjadi landasan dan sumber dari peraturan perundang-undangan di bawahnya dicabut atau diganti maka 
peraturan-peraturan perundangan dibawahnya harus menyesuaikan kembali dengan peraturan perudangan terbaru di atasnya. Salah satu kendala yuridis dibidang pengelolaan DAS adalah perundang-undangan yang berkaitan dengan sumber daya air mengalami beberapa pergantian sehingga hal tersebut menjadi kendala yuridis dikarenakan peraturan pelaksana dibawahnya harus disesuaikan dengan peraturan perundang-undangan yang terbaru.

Sebelum disahkan Undang-Undang Nomor 17 Tahun 2019 tentang Sumber Daya Air pada Oktober 2019, ketentuan mengenai sumber daya air berdasarkan Undang-Undang Nomor 11 Tahun 1974 tentang Pengairan. Hal ini dikarenakan keberlakuan Undang-Undang Nomor 7 Tahun 2004 tentang Sumber Daya Air pada 2013 dibatalkan oleh Mahkamah Konstitusi secara keseluruhan berdasarkan Putusan Mahkamah Konstitusi Nomor 85/PUU-XII/2013 atas uji materi UndangUndang Nomor 7 Tahun 2004 tentang Sumber Daya Air. Mahkamah Konstitusi (MK) membatalkan keberlakuan secara keseluruhan Undang-Undang Nomor 7 Tahun 2004 tentang Sumber Daya Air karena tidak memenuhi enam prinsip dasar pembatasan pengelolaan sumber daya air. Keputusan MK tersebut membatalkan Undang-Undang Sumber Daya Air karena oleh MK dianggap penerapan pasalpasalnya membuka peluang privatisasi dan komersialisasi pihak swasta atas pengelolaan sumber daya alam yang merugikan masyarakat sebagai pengguna air. Pembatalan Undang-Undang Sumber Daya Air tersebut mengembalikan hak pengelolaan air kepada Negara.

Hal ini tentunya menimbulkan permasalahan yuridis di bidang pengelolaan DAS pada kurun waktu tahun 2004 sampai dengan tahun 2019 karena dengan dibatalkan Undang-Undang Nomor 7 Tahun 2004 tentang Sumber Daya Air, negara memberlakukan kembali Undang-Undang Nomor 11 Tahun 1974 tentang Pengairan selama belum dibentuk undang-undang baru yang menggantikan Undang-Undang Sumber Daya Air. Implikasi putusan MK Mengenai Pembatalan Undang-Undang Sumber Daya Air mengakibatkan Peraturan Pemerintah, Peraturan Presiden, Keputusan Presiden, dan Peraturan Menteri yang merupakan aturan pelaksana dari Undang-Undang Sumber Daya Air tidak memiliki dasar hukum berlaku yang mengikat. 
Peraturan Pemerintah Republik Indonesia Nomor 37 Tahun 2012 tentang Pengelolaan Daerah Aliran Sungai merupakan salah satu Peraturan Pemerintah yang merupakan aturan pelaksana dari Undang-Undang Nomor 7 Tahun 2004 tentang Sumber Daya Air sehingga kedudukan Peraturan Pemerintah Republik Indonesia Nomor 37 Tahun 2012 ini apabila dikaji menurut teori hierarki perundang-undangan berjenjang ${ }^{20}$ dan berkelompok (Von Stufennaufbau De Rechtsordnung)21, menjadi tidak mempunyai kekuatan hukum yang mengikat karena dasar hukum pembentukan PP tersebut telah dibatalkan oleh Mahkamah Konstitusi.

Keberlakuan Peraturan Pemerintah Nomor 37 Tahun 2012 tentang Pengelolaan Daerah Aliran Sungai apabila dikaji berdasarkan teori dari Hans Nawiasky karena kedudukan Peraturan Pemerintah tersebut sebagai peraturan pelaksana akan sangat tergantung kepada norma yang ada di atasnya, yang menjadi gantungan atau dasar bagi berlakunya norma tersebut. Ketentuan-ketentuan yang digariskan oleh suatu norma yang lebih tinggi merupakan das sollen bagi pembentukan norma yang lebih rendah. Dengan demikian, Peraturan Pemerintah tersebut yang sejatinya adalah norma hukum yang lebih rendah dengan sendirinya tidak berlaku lagi, apabila norma hukum yang ada diatasnya yang menjadi dasar dan menjadi sumber berlakunya norma tersebut dicabut atau dihapus. Namun, praktik ketatanegaraan di Indonesia, apabila ada suatu norma hukum yang lebih tinggi yang dijadikan dasar atau sumber berlakunya norma hukum yang lebih rendah dicabut atau dihapus atau dibatalkan maka untuk norma hukum yang lebih rendah masih tetap berlaku sepanjang tidak bertentangan dengan peraturan perundang-undangan yang masih berlaku dan sepanjang belum dibentuk undang-undang yang baru yang menggantikan undang-undang yang telah dicabut atau dihapus atau dibatalkan demi mencegah kekosongan hukum. Hal ini tentunya menimbulkan permasalahan baru karena seringkali undang-undang yang telah dicabut atau diganti atau dibatalkan tidak segera dibentuk undang-undang yang baru yang lebih responsif. Peraturan-peraturan pelaksana yang masih berlaku menjadi tidak mempunyai dasar berlaku norma hukum yang lebih tinggi yang mengikat kuat karena substansi

\footnotetext{
${ }_{20}$ Maria Farida Indrati Soeprapto, “Ilmu Perundang-Undangan (1) Jenis, Fungsi, Materi Muatan”, Kanisius, Yogyakarta, 2007, hlm. 41.

21 I Gde Pantja Astawa, "Dinamika Hukum Dan Ilmu Perundang-Undangan Di Indonesia", PT. Alumni, Bandung, 2008, hlm. 37
} 
pengaturan undang-undang yang sebelumnya masih sangat sederhana dan belum memenuhi kebutuhan masyarakat.

Dasar hukum pembentukan PP Nomor 37 Tahun 2012 yang sudah tidak berlaku antara lain Undang-Undang Nomor 32 Tahun 2004 tentang Pemerintahan Daerah dan Undang-Undang Undang-Undang Nomor 7 Tahun 2004 tentang Sumber Daya Air. Peraturan Pemerintah Nomor 37 Tahun 2012 ini perlu untuk dilakukan perubahan terlebih dahulu menyesuaikan dasar hukum pembentukannya berdasarkan peraturan perundang-undangan yang sejajar dan peraturan perundangundangan yang lebih tinggi yang masih berlaku sehingga mempunyai kekuatan hukum yang mengikat yang kuat. Konsideran dalam PP Pengelolaan DAS Perlu disesuaikan dulu dengan Undang-Undang Pemerintahan Daerah yang baru.

Dalam salah satu pertimbangan yuridis yang menjadi dasar pembentukan Peraturan Pemerintah Nomor 37 Tahun 2012 adalah Pasal 18 Undang-Undang Nomor 7 Tahun 2004 tentang Sumber Daya Air, yang mengatur bahwa sebagian kewenangan pemerintah dalam pengelolaan sumber daya air dapat diselenggarakan oleh pemerintah daerah, dalam rangka mendukung terselenggaranya pengelolaan Daerah Aliran Sungai. Dengan dibatalkannya UU Nomor 7 Tahun 2004 secara otomatis pertimbangan yuridis yang menjadi dasar pembentukan PP 37 Tahun 2012 menjadi tidak berlaku. Hal ini tentunya sangat berimplikasi terhadap pengaturan mengenai pengelolaan DAS kembali lagi berdasarkan Undang-Undang tentang Pengairan. Namun pada bulan Oktober Tahun 2019, UU Pengairan telah dicabut dan diganti dengan Undang-Undang Nomor 17 Tahun 2019 tentang Sumber Daya Air. Hal ini berarti segala peraturan pelaksana yang berkaitan dengan pengelolaan DAS termasuk juga Peraturan Pemerintah Nomor 37 Tahun 2012 harus segera disesuaikan dengan UU SDA yang terbaru.

Berdasarkan Undang-Undang Nomor 17 Tahun 2019 tentang Sumber Daya Air maka UU Pengairan menjadi tidak berlaku kembali sehingga kewenangan pengelolaan DAS selanjutnya mengacu kepada Pasal 9 ayat (1) UU Nomor 17 Tahun 2019 yang menyatakan bahwa atas dasar penguasaan negara terhadap Sumber Daya Air maka Pemerintah Pusat dan/atau Pemerintah Daerah diberi tugas dan wewenang untuk mengatur dan mengelola Sumber Daya Air. Selanjutnya dalam Pasal 10 dan 11 UU Nomor 17 Tahun 2019 diatur mengenai tugas 
dan kewenangan Pemerintah Pusat secara lebih jelas dan terperinci. Selanjutnya dalam Pasal 12 dinyatakan bahwa tugas dan wewenang Pemerintah Daerah sebagaimana dimaksud dalam Pasal 9 ayat (1) meliputi tugas dan wewenang Pemerintah Daerah provinsi dan/atau Pemerintah Daerah kabupaten/ kota. Dalam Pasal 13 dan Pasal 14 UU Nomor 17 Tahun 2019 diatur mengenai tugas dan wewenang Pemerintah Daerah Provinsi secara terperinci dan jelas.

Pada Undang-Undang SDA yang terbaru dalam Pasal 12 mengamanatkan bahwa tugas dan wewenang Pemerintah Daerah meliputi tugas dan wewenang Pemerintah Daerah provinsi dan/atau Pemerintah Daerah kabupaten/ kota. Dalam UU Pemerintahan Daerah, pemerintah Daerah Kabupaten/Kota tidak diberikan kewenangan untuk melaksanakan pengelolaan DAS Sedangkan pada UU SDA terbaru, diatur mengenai tugas dan kewenangan Pemerintah Kabupaten/Kota berkaitan dengan pengaturan dan pengelolaan Sumber Daya Air yang tentunya hal ini sangat berkaitan dengan Pengelolaan DAS. Selanjutnya berkaitan dengan disahkannya UU SDA baru maka segala peraturan pelaksana yang berkaitan dengan sumber daya air termasuk didalamnya terkait pengelolaan DAS harus segera menyesuaikan dengan Substansi UU SDA yang terbaru yaitu dalam UU Nomor 17 Tahun 2019.

2. Kendala Yuridis berupa Pengaturan Kewenangan Penyelenggaraan dan Pelaksanaan Pengelolaan DAS dalam Undang-Undang Nomor 23 Tahun 2014 tentang Pemerintahan Daerah.

Dalam Undang-Undang Nomor 23 Tahun 2014 tentang Pemerintahan Daerah, Pemerintah Kabupaten /Kota tidak memiliki kewenangan untuk melaksanakan pengelolaan DAS. Kewenangan pengelolaan DAS diselenggarakan oleh Pemerintah Pusat, sedangkan berkaitan dengan pelaksanaan pengelolaan DAS lintas Daerah kabupaten/kota dan dalam Daerah kabupaten/kota dalam 1 (satu) Daerah provinsi menjadi urusan dari pemerintah daerah provinsi. Selanjutnya dalam ketentuan dalam Lampiran Undang-Undang Pemerintahan Daerah juga tidak mengatur secara mendetail mengenai tanggung jawab dan kewenangan Pemerintah Pusat dan Pemerintah Provinsi secara mendetail berkaitan dengan Pengelolaan DAS. Hal ini menjadi hambatan bagi pihak Pemerintah Kabupaten/Kota dalam pengelolaan DAS di tingkat kabupaten/kota 
karena mereka tidak memiliki kewenangan dalam pengelolaan DAS berdasarkan UU Pemerintahan Daerah. Pemerintah Kabupaten/Kota sebagai pihak yang paling memahami permasalahan pengelolaan DAS di tingkat Kabupaten/Kota idealnya diberikan kewenangan oleh Pemerintah Pusat untuk melaksanakan pengelolaan DAS. Ketentuan mengenai kewenangan penyelenggaraan pengelolaan DAS dalam UU Pemerintahan Daerah juga ternyata tidak sinkron dengan Undang-Undang Nomor 37 Tahun 2014 tentang tentang Konservasi Tanah dan Air yang menyatakan bahwa penyelenggara konservasi tanah adalah Pemerintah Pusat, Pemerintah Daerah Provinsi dan Pemerintah Kabupaten /Kota. Oleh sebab itu diperlukan sinkronisasi dan harmonisasi beberapa peraturan perundang-undangan yang berkaitan dengan pengelolaan DAS.

\section{Pengaturan Ideal Pengelolaan Daerah Aliran Sungai di Indonesia}

Mengacu pada permasalahan pengelolaan DAS yang dihadapi DAS Sungai Serang Kabupaten Kulon Progo secara garis besar meliputi: pertama, permasalahan biogeofisik meliputi permasalahan sumber daya lahan (land resources). permasalahan sumber daya air (water resources), erosi dan sedimentasi. Kedua, permasalahan sosial. budaya dan kelembagaan, koordinasi dan sinergi dalam pengelolaan DAS secara terpadu. Ketiga, permasalahan ketidaksinkronan peraturan perundang-undangan berkaitan dengan kewenangan pengelolaan DAS. Berbagai permasalahan atau kendala-kendala mengenai pengelolaan DAS Serang baik dalam aspek yuridis maupun aspek lainnya seperti aspek biogesik, sosial, ekonomi, budaya, kelembagaan, koordinasi dan sinergi dalalam pengelolaan DAS maka sangat diperlukan bentuk pengaturan yang ideal yang harus diimplementasikan untuk menyelesaikan permasalhan tersebuut di atas.

Berkaitan dengan permasalahan pengelolaan DAS di Indonesai maka bentuk pengaturan ideal pengelolaan Daerah Aliran Sungai di Indonesia diformulasikan sebagai berikut: Pertama, terkait dengan disahkannya UU Sumber Daya Air yang terbaru yaitu UU Nomor 17 Tahun 2019 tentang Sumber Daya Air, menjadi landasan hukum yang melengkapi kelemahan dari UU Pemerintahan Daerah yang hanya mengatur kewenangan pengelolaan DAS hanya pada Pemerintah Pusat dan Pemerintah Daerah Provinsi. Dalam UU SDA yang baru, pemerintah 
Kabupaten/Kota diberikan tugas dan kewenangan terkait pengaturan dan pengelolaan DAS khususnya dalam Pasal 15 dan Pasal 16. UU SDA yang baru juga telah sesuai dan sinkron dengan Undang-Undang Nomor 37 Tahun 2014 tentang Konservasi Tanah dan Air karena dalam UU Konservasi Tanah dan Air, karena berkaitan dengan penyelenggaraan konservasi tanah dan air maka diberikan kewenangan baik Pemerintah Pusat, pemerintah daerah Provinsi, maupun pemerintah daerah Kabupaten/Kota. Terkait tugas dan kewenangaan pengelolaan sumber daya air dalam UU SDA baru, maka pemerintahan daerah kabupaten/kota dapat membuat kebijakan-kebijakan terkait pengelolaan DAS di daerahnya. Berkaitan dengan tugas dan kewenangan yang diatur dalam UU SDA yang baru maka hal ini membuat lebih mudah penanganan-penanganan permasalahan pengelolaan DAS di setiap daerah lebih cepat ditangani. Pemerintah Daerah Kabupaten/Kota dapat mengambil langkah-langkah yang cepat dan efektif melalui kebijakan-kebijakan daerah kabupaten/kota yang dikeluarkan dan diimplementasikan. Kedua, terkait kewenangan pengelolaan DAS yang diatur dalam UU Pemerintahan Daerah, Dalam UU Pemerintahan Daerah terkait pengelolaan DAS, Pemerintah Daerah Kabupaten/Kota tidak memiliki kewenangan untuk melaksanakan pengelolaan DAS sehingga hal ini tentunya menyulitkan Pemerintah Daerah Kabupaten/Kota ketika akan menangani permasalahan pengelolaan DAS. Dalam hal ini maka Pemerintah Daerah Provinsi dapat melakukan sinkronisasi melalui mandat tugas pembantuan sub-urusan pengelolaan DAS dari pemerintah daerah provinsi ke pemerintah kabupaten / kota. $^{22}$

22 Paimin and Priyono, "Pengelolaan Daerah AliranSungai Dalam Bingkai Peraturan PerundangUndangan,” n.d., https:/ / www.forda-mof.org//files/ppt_paimin.pdf. diakses pada tanggal 18 September 2020 
Gambar 1.23

Sinkronisasi Kewenangan Urusan Pengelolaan DAS Tingkat Kabupaten/Kota

UU No. 23 Tahun 2014

(Berdasarkan lampiran UU

Pemerintahan Daerah bahwa Urusan pengelolaan DAS hanya Pemerintah (Pusat) sebagai penyelenggara dan pemerintah daerah Provinsi sebagai
UU No. 37 Tahun 2014

(penyelenggara konservasi tanah adalah Pemerintah (Pusat), pemerintah daerah Provinsi, dan pemerintah daerah Kabupaten/Kota.

Apabila kedua undang-undang tidak diselaraskan pada peraturan perundangundangan turunannya, penyelenggara pemerintahan menjadi serba salah.

Sinkronisasi melalui mandat tugas pembantuan dari pemerintah daerah provinsi ke pemerintah daerah kabunaten/ kota

Ketiga, peraturan-peraturan pelaksana terkait pengelolaan DAS harus harus segera disesuaikan dengan Peraturan perundang-undangan di atasnya atau yang lebih tinggi mengingat telah ada pencabutan UU Pengairan dan Pemberlakuan UU SDA yang baru. Peraturan-peraturan pelaksana hendaknya disesuaikan sesuai dengan perubahan substansi peraturan perundang-undangan yang berada diatasnya antara lain UUD NRI 1945 dan juga undang-undang formil antara lain : UU Pemerintahan Daerah, UU Sumber Daya Air dan UU Konservasi Tanah dan Air sehingga terwujud harmonisasi dan sinkronisasi peraturan perundangundangan. Pengelolaan DAS sangat berkaitan erat khususnya regulasi yang berkaitan dengan sumber daya air, penataan ruang, pemerintahan daerah serta konservasi tanah dan air. Pengelolaan DAS dilaksanakan sesuai dengan rencana tata ruang dan pola pengelolaan sumber daya air sesuai dengan ketentuan peraturan perundang-undangan di bidang penataan ruang dan sumber daya air.

Sebelum disahkannya UU SDA yang baru, belum ada pengaturan yang mendetail mengenai tanggung jawab dan kewenangan antara Pemerintah Pusat, Pemerintah Daerah Provinsi dan Pemerintah Daerah Kabupaten/Kota di bidang Pengelolaan DAS dan belum adanya sinkronisasi perundang-undangan menyebabkan peraturan pelaksana di tingkat daerah menjadi tidak begitu efektif 
karena peraturan yang lebih tinggi yang menjadi dasar berlakunya Peraturan Pelaksana di daerah masih belum sinkron. Selain itu, Undang-Undang Pengairan substansinya sangat sederhana. Dengan disahkan dan diundangkannya UU SDA yang baru memberikan dasar legitimasi kepada Pemerintah Pusat, Pemerintah Daerah Provinsi dan Pemerintah Daerah Kabupaten/Kota sehingga masing-masing memiliki tugas dan kewenangan yang tegas, jelas dan terperinci dalam pengelolaan DAS di Indonesia dan menjadi salah satu sumber berlakunya bagi Peraturan perundang-undangan di bawahnya yang khususnya mengatur tentang Pengelolaan DAS sehingga mempunyai kekuatan hukum yang mengikat. Dengan diaturnya tugas dan kewenangan pengelolaan DAS maka Pemerintah Daerah Kabupaten/kota sudah tidak kesulitan dan serba salah dalam mengambil segala kebijakan dan tindakan-tindakan hukum berkaitan pengelolaan DAS di Daerah Kabupaten /Kota.

Pengelolaan DAS perlu dilakukan secara terpadu dengan melibatkan berbagai pemangku kepentingan pengelolaan DAS yang terdiri dari unsur masyarakat, dunia usaha, Pemerintah Pusat, Pemerintah daerah provinsi, Pemerintah Daerah Kabupaten/Kota. dengan prinsip-prinsip keterpaduan, kesetaraan, dan berkomitmen untuk menerapkan penyelenggaraan pengelolaan sumberdaya alam yang adil, efektif, efisien, dan berkelanjutan. Dalam penyelenggaraan pengelolaan DAS terpadu tersebut diperlukan perencanaan yang komprehensif yang mengakomodasikan berbagai kepentingan dan melibatkan berbagai unsur/pemangku kepentingan sehingga keseimbangan sumberdaya alam dengan manusia dan segala aktivitasnya dapat mewujudkan kondisi tata air yang optimal, baik kualitas, kuantitas maupun distribusinya serta terkendalinya erosi. Pengelolaan DAS secara terpadu harus berpedoman pada aspek ekonomi, sosial budaya dan ekologi dan dituangkan dalam bentuk pengaturan yang ideal dalam undang-undang formil dan peraturan-peraturan pelaksana sehinggamempunyai daya mengikat dan efektif.

\section{Penutup}

Pengelolaan Daerah Aliran Sungai (DAS) sangat berkaitan dengan peraturan perundang-undangan pada bidang pemerintahan daerah, sumber daya air, penataan ruang, serta konservasi tanah dan air. Segala bentuk peraturan 
perundang-undangan yang berkaitan dengan pengelolaan DAS harus diatur secara tegas sebagai dasar hukum pengelolaan DAS di Indonesia. Permasalahan berkaitan dengan pengelolaan DAS di Indonesia (Studi Kasus di Sungai Serang,Kabupaten Kulon Progo), dalam Rencana pengelolaan DAS pada Sungai Serang, telah mengidentifikasi masalah pada DAS Sungai Serang antara lain, pertama, permasalahan biogeofisik meliputi permasalahan sumber daya lahan (land resources). permasalahan sumber daya air (water resources), erosi dan sedimentasi. Kedua, permasalahan sosial. budaya dan kelembagaan, koordinasi dan sinergi dalam pengelolaan DAS secara terpadu. Ketiga, permasalahan ketidaksinkronan peraturan perundang-undangan berkaitan dengan kewenangan pengelolaan DAS menyebabkan Pemerintah Daerah Kabupaten/kota serba salah mengambil tindakan-tindakan hukum atau kebijakan

Kendala-kendala yuridis dalam pengelolaan DAS di Indonesia berkaitan dengan Pencabutan dan Pergantian Undang-Undang Sumber Daya Air; ketidak sinkronan antara UU Sumber Daya Air, UU pemerintahan Daerah dan UU Konservasi Tanah dan Air; terkait kewenangan penyelenggaraan dan pelaksanaan pengelolaan DAS dalam Undang-Undang Nomor 23 Tahun 2014 tentang Pemerintahan Daerah.

Berdasarkan kendala-kendala yuridis yang berhasil diidentifikasi, maka penulis merumuskan bentuk pengaturan ideal pengelolaan DAS antara lain Pemerintah Daerah Kabupaten/Kota dapat mengambil langkah-langkah yang cepat dan efektif melalui kebijakan-kebijakan daerah kabupaten/kota yang dikeluarkan dan diimplementasikan daerahnya berdasarkan tugas dan kewenangan yang diatur dalam UU SDA yang baru; Pemerintah Daerah Provinsi dapat melakukan sinkronisasi melalui kebijakan berupa mandat tugas pembantuan sub-urusan pengelolaan DAS dari pemerintah daerah provinsi ke pemerintah kabupaten / kota; Peraturan-peraturan pelaksana terkait pengelolaan DAS harus segera disesuaikan dengan Peraturan perundang-undangan di atasnya atau yang lebih tinggi mengingat telah ada pencabutan UU Pengairan dan Pemberlakuan UU SDA yang baru; dan Pengelolaan DAS secara terpadu harus berpedoman pada aspek ekonomi, sosial budaya dan ekologi dan dituangkan 
dalam bentuk pengaturan yang ideal dalam undang-undang formil dan peraturan-peraturan pelaksana sehingga mempunyai daya mengikat dan efektif.

\section{Daftar Pustaka}

\section{Buku}

Astawa, I Gede Pantja. Dinamika Hukum Dan Ilmu Perundang-Undangan Di Indonesia. PT. Alumni, Bandung, 2008.

Ibrahim, Johnny, Teori Dan Metodologi Penelitian Hukum Normatif, Bayu Media Publishing, Malang, 2011.

Marzuki, Peter Mahmud, Penelitian Hukum, Prenada Media Grup, Jakarta, 2009

Naharuddin, Herman Harijanto, and Abdul Wahid, Pengelolaan Daerah Aliran Sungai Dan Aplikasinya Dalam Proses Belajar Mengajar, Cetakan Pertama, UNTAD Press, Palu, 2018.

Penyusun, Tim." Rencana Pengelolaan Daerah Aliran Sungai Serang Tahun 20122027", Kementerian Lingkungan Hidup dan Kehutanan Direktorat Jenderal Pengendalian Daerah Aliran Sungai dan Hutan Lindung Balai Pengelolaan Daerah Aliran Sungai dan Hutan Lindung Serayu,Opak, Progo, 2017.

Soeprapto, Maria Farida Indrati "Ilmu Perundang-Undangan(1) (Jenis, Fungsi, Materi Muatan", Kanisius, Yogyakarta, 2007.

\section{Jurnal}

Adi Susetyaningsih, "Pengaturan Penggunaan Lahan di Daerah Hulu Das Cimanuk Sebagai Upaya Optimalisasi Pemanfaatan Sumberdaya Air," Jurnal Konstruksi Sekolah Tinggi Teknologi Garut, Volume 10, No. 01, Tahun 2012.

Agung Setyawan, Totok Gunawan, Suprapto Dibyosaputro, Sri Rum Giyarsih, Jasa Dan Etika Lingkungan Untuk Pengendalian Air Dan Banjir Sebagai Dasar Pengelolaan Das Serang, Jurnal Pembangunan Wilayah \& Kota, Voume 14 Nomor 4, Desember 2018.

H. Satriawan, Strategi Pengelolaan Daerah Aliran Sungai (Das) Dalam Rangka Optimalisasi Kelestarian Sumberdaya Air (Studi Kasus DAS Peusangan Aceh), Majalah Ilmiah Universitas Almuslim, Volume 9 (Edisi Khusus Dies Natalies), 2017.

Ismah Pudji Rahayu Ishak, Andi Idham Asman, Despry Nur Annisa Ahmad, "Pemanfaatan Teknologi Spasial Dalam Pengelolaan Daerah Aliran Sungai (Das) Binanga Lumbua Kabupaten Jeneponto Sulawesi Selatan", Jurnal Geomatika, Volume 22 Nomor 1, Mei 2016.

Khabibi Nurrofi' Pratama, Kukuh Murtilaksono, Hendrayanto, "Pengembangan Kelembagaan Penggunaan Lahan Di Das Catur Kabupaten Madiun," Jurnal Tataloka, Volume 19, No. 2, Mei 2017. 
Muhammad Fatahilah, "Kajian Keterpaduan Pengelolaan Daerah Aliran Sungai (Das) Garang Provinsi Jawa Tengah", Jurnal Geografi, Volume 10 No. 2, Juli 2013.

Sudaryono, "Pengelolaan Daerah Aliran Sungai (Das) Terpadu, Konsep Pembangunan Berkelanjutan," Jurnal Teknologi Lingkungan, Volume 3, No. 2, Mei 2002.

\section{Internet}

"DAS Kritis: Tantangan Sains Pengelolaan DAS di Indonesia". http://www.menlhk.go.id/ website: http://www.menlhk.go.id/site/ single_post/1618, diakses pada tanggal 18 September 2020

"Pengelolaan Daerah AliranSungai Dalam Bingkai Peraturan PerundangUndangan," n.d., https://www.forda-mof.org//files/ppt_paimin.pdf. diakses pada tanggal 18 September 2020

\section{Peraturan Perundang-undangan}

Undang-Undang Dasar Negara Republik Indonesia Tahun 1945

Undang-Undang Nomor 32 Tahun 2009 tentang Perlindungan dan Pengelolaan Lingkungan Hidup, Lembaran Negara Republik Indonesia Tahun 2009 Nomor 140, Tambahan Lembaran Negara Republik Indonesia Nomor 5059

Undang-Undang Nomor 12 Tahun 2011 tentang Pembentukan Peraturan Perundang-undangan, Lembaran Negara Republik Indonesia Tahun 2011 Nomor 82, Tambahan Lembaran Negara Republik Indonesia Nomor 5234

Undang-Undang Nomor 23 Tahun 2014 tentang Pemerintahan Daerah sebagaimana telah diubah terakhir dengan Undang-Undang Nomor 9 Tahun 2015 tentang Perubahan Kedua Atas Undang-Undang Nomor 23 Tahun 2014 tentang Pemerintahan Daerah, Lembaran Negara Republik Indonesia Tahun 2015 Nomor 58, Tambahan Lembaran Negara Republik Indonesia Nomor 5679

Undang-Undang Nomor 37 Tahun 2014 tentang Konservasi Tanah dan Air, Lembaran Negara Republik Indonesia Tahun 2014 Nomor 299, Tambahan Lembaran Negara Republik Indonesia Nomor 5508

Undang-Undang Nomor 17 Tahun 2019 tentang Sumber Daya Air, Lembaran Negara Republik Indonesia Tahun 2019 Nomor 190, Tambahan Lembaran Negara Republik Indonesia Nomor 6405

Peraturan Pemerintah Nomor 37 Tahun 2012 tentang Pengelolaan Daerah Aliran Sungai, Lembaran Negara Republik Indonesia Tahun 2012 Nomor 62, Tambahan Lembaran Negara Republik Indonesia Nomor 5292

Peraturan Daerah Daerah Istimewa Yogyakarta Nomor 11 Tahun 2016 Tentang Pengelolaan Daerah Aliran Sungai, Lembaran Daerah Daerah Istimewa Yogyakarta Tahun 2016 Nomor 11, Tambahan Lembaran Daerah Daerah Istimewa Yogyakarta Nomor 11. 